Synthesis, part of a Special Feature on The Energy-Water Nexus

\title{
Exploiting Soil-Management Strategies for Climate Mitigation in the European Union: Maximizing "Win-Win" Solutions across Policy Regimes
}

\author{
$\underline{\text { Christian Bugge Henriksen }}^{1}, \underline{\text { Karen Hussey }}^{2}$, and Peter E. Holm ${ }^{3}$
}

\begin{abstract}
The Intergovernmental Panel on Climate Change (IPCC) has identified a number of soil-management strategies that can be implemented to reduce GHG emissions. However, before deciding which of these strategies are most appropriate in any given situation, it is important to investigate how these strategies affect other aspects of sustainable development. For instance, some attempts to sequester carbon in the landscape could alter the soil's capacity to filter water. Alternatively, other strategies could unintentionally increase net energy consumption through greater fertilizer use. Focusing specifically on opportunities to implement soil-management strategies in the European Union (EU), we discuss the synergies and trade-offs of those strategies with respect to water resources management and energy security. The focus of the analysis is two-fold: first, we analyze the net benefit of strategies such as crop management, nutrient management, tillage and residue management, water management, and bioenergy vis-a-vis their implications for water resources and energy security; second, we undertake an assessment of the EU's relevant policy frameworks to assess whether the potential synergies from various soil-management strategies are being encouraged or, conversely, where perverse outcomes or trade-offs are likely. Our findings suggest there is much scope to encourage soil-management strategies in Europe that would mitigate greenhouse gas emissions, but these synergies are currently not fully exploited at the EU policy level. We identify a number of options for better policy integration among the Common Agricultural Policy, the Water Framework Directive, and the Climate Action and Renewable Energy Package.
\end{abstract}

Key Words: Climate Action and Energy Package; climate change mitigation; Common Agricultural Policy; energy security; European Union; greenhouse gas emissions; soil management; Water Framework Directive

\section{INTRODUCTION}

As stated by Campbell (2008), "The time is ripe for refocusing on soil stewardship as a key to improving water productivity, energy productivity and food security while reducing net greenhouse gas emissions from agriculture." Certainly, with an estimated global carbon content of $1.500 \mathrm{Gt}$, soil represents the largest carbon sink on our planet (Amundsen 2001) and, as about $99 \%$ of the world's food and fibers are produced on soil/land, a thorough understanding of how soil can be manipulated to increase carbon sequestration is crucial for mitigating greenhouse gas (GHG) emissions. Furthermore, changes in agricultural practices and the use of biofuels could potentially reduce emissions directly or displace emissions from other sources (Smith et al. 2008). However, there is increasing awareness of the limits of biomass production set by the other soil functions, in particular the soil's ability to filter water, sequester carbon, and attenuate nutrients as well as the need to maintain biological diversity.

The Intergovernmental Panel on Climate Change (IPCC) has identified a number of soil-management strategies that may be applied to reduce GHG emissions (Smith et al. 2007). Nevertheless, before deciding which of these strategies are most appropriate in any given situation, it is important to investigate how these strategies affect other aspects of sustainable development. It is evident that although some of the soil-management strategies available may have positive effects, others may have negative social, economic, and environmental effects. As Hussey and Schram (2011) highlight, the three sectors-energy, water, and food-have until recently been formulated by distinct groups of stakeholders with little interaction or understanding between them. This division is also true in the research community, where experts focus on the topics within disciplines but unless incentives are strong they fail to interact with, and therefore take account of, experts in different but related fields of research. This lack of coordination and integration filters down to policy makers, who are required to make decisions based on incomplete, sector-specific data. The results are policies that are effective in one domain, but which may undermine the objectives in other domains (Hussey and Schram 2011).

We focus on the opportunities to implement soil-management strategies in the European Union (EU), as part of its ambitious targets to tackle climate change. Through its Climate Action and Renewable Energy (CARE) Package, the EU has committed to a $20 \%$ reduction in GHG emissions by 2020 , and a $20 \%$ share of renewable energies in EU energy consumption by 2020 (European Commission 2009). In parallel, the EU seeks to sustain agricultural production governed by the sustainability criterion, which implies that the quality of Europe's soil resources must not degrade over time 
and that those resources should be managed in a way that minimizes adverse effects in the connected aqueous and atmospheric environments (European Commission 2006). However, one could argue that there may be hidden or unintended consequences from the EU's climate change policies on its soil functionality or water quality, potentially pitting the policy regimes against one another. Similarly, there may be opportunities from soil-management strategies to mitigate GHG emissions that are currently overlooked in favor of other policy objectives or because of a lack of integration between the EU's key policy directives governing climate change, energy, agriculture, and water.

\section{ANALYTICAL FRAMEWORK AND TERMINOLOGY}

In our assessment of those soil-management strategies most appropriate for use in the EU, "synergies" are those strategies that provide net positive outcomes in terms of: reducing GHG emissions, maintaining the integrity of the water resource base, maintaining or reducing net energy use, and retaining or maintaining soil quality and functionality. In other words, "synergies" are "win-win" scenarios. On the other hand, "trade-offs" refers to unintended negative or perverse outcomes which may arise from the implementation of a given soil-management strategy, for instance if the net energy use is higher owing to increased fertilizer use, or if increasing demands on water resources outweigh the potential benefits from a reduction in emissions. Of course, in some cases, for instance the application of biochar to soil to sequester carbon-there are still uncertainties surrounding the science and the potential environmental impacts of those strategies remains unclear (Lehman 2007, Sohi et. al. 2010). Similarly, with issues such as soil management and agricultural practices, a "one-size-fits-all" approach is not always appropriate, as techniques and practices that are suitable in one environment may be unsuitable in another. Nevertheless, there are proven, broadly applicable management strategies that will enhance soil quality and functionality with knock-on benefits for water retention, and that present opportunities to sequester carbon, reduce fertilizer use, and potentially even increase agricultural yield. It is for this reason that protecting our soil is, in some senses, the "low-hanging fruit" in any climate mitigation strategy, and opportunities to exploit these strategies should be maximized.

We first examine the soil-management strategies espoused by the IPCC that are most relevant for the European Union: crop management, nutrient management, tillage and residue management, water management, soil restoration, and bioenergy. Our objective is to isolate those strategies that have synergistic qualities with water and energy security; that is, they won't make things worse and, importantly, where the net marginal benefit is high; that is, they offer significant gains for climate mitigation objectives. We then analyze the key policies that govern soil, climate change, energy, and water policies in the EU to ascertain the extent to which those policies encourage the uptake of synergistic soil-management strategies. The intention is not to explore individual member states' agricultural, energy, water, and climate change policies but, rather, the basis of the research is a "thin institutionalism" approach that emphasizes the need to assess policy design, settings, and institutional arrangements to better understand government priorities and choices (Young 2002, see also Pittock 2011). In this sense, and as Rockman (1994, in Reich 2000) has observed, "institutional arrangements make opportunities more or less available and increase or decrease the risk of acting." In the EU, in the areas of climate change, energy, water, and agriculture, the policy framing and settings are established at the supranational level, through European "directives" that set legally binding objectives and parameters that member states must pursue. Thus, it is important to examine the high-level, policy framing of the EU's sectoral regimes (climate, energy, agriculture, water, etc.) to ascertain what the priorities are and where the changes in behavior might occur. Finally, we explore possible reforms or developments that might increase the uptake of synergistic soil-management strategies in the EU's climate, energy, water, and agricultural policies. This necessarily draws on the literature relating to environmental policy integration, and we speculate on some of the ideas in that research domain that might be useful to achieve greater consistency and coordination in EU environmental policies.

\section{SOIL-MANAGEMENT STRATEGIES TO REDUCE GHG EMISSIONS}

When identifying soil-management strategies with the potential to mitigate GHG emissions, it is useful to divide them into different categories, depending on their focus, i.e., crop management, nutrient management, tillage and residue management, water management, soil restoration, and bioenergy. We will now examine soil-management strategies in each of these categories and assess their synergies and tradeoffs with respect to water resources and energy security.

\section{Crop Management}

The IPCC mean estimate of the GHG mitigation potentials of improved crop management options range from 0.39 to 0.98 $\mathrm{t} \mathrm{CO}_{2}$-eq ha ${ }^{-1} \mathrm{yr}^{-1}$ in dry and moist climatic zones (Smith et al. 2007). In Europe, which is characterized by a moist climatic zone, there are several ways to improve crop management for GHG mitigation, the most important ones being: 1) optimizing crop rotations for carbon sequestration by increasing the fraction of perennial crops, leguminous crops, and crops with a high carbon content in crop residues, 2) increasing energy efficiency by adopting high yielding varieties, 3) replacing bare fallow with fallow crops, and 4) introducing winter cover crops planted in late summer or autumn.

Studies show that a complete conversion of arable land to permanent grass is estimated to increase soil carbon by $0.5 \mathrm{t} /$ $\mathrm{yr}^{-1} / \mathrm{ha}^{-1}$ (IPCC 2000, Conant et al. 2001), whereas temporary 
grass may increase soil carbon by $0.35 \mathrm{t} / \mathrm{yr}^{-1} / \mathrm{ha}^{-1}$ (Soussana et al. 2004). The water requirements for permanent grass and temporary grass are lower than for most other arable crops; for example, cereals and maize require $10 \%$ more water than grass (Food and Agriculture Organization 1991). Furthermore, a higher level of soil organic matter will also increase the water-holding capacity of the soil and thereby reduce losses from drainage. There is no tillage in the year after the grass has been planted, and this will reduce the energy use for tillage corresponding to the ratio of grass in the crop rotation. The area with permanent grass in the EU was $51,096,000$ ha in 2009 , whereas the area of temporary grass was 8.164 .400 ha (Eurostat 2011). Correspondingly, the area with cereals was 58,016,400 ha, and the area of silage maize was 5.257.500 ha. A possible scenario that may increase the area of permanent grass and/or temporary grass without reducing agricultural productivity is a shift from dairy production based on silage maize to a dairy production based on grass. For instance, if $50 \%$ of the area with silage maize is replaced by permanent grass, GHG emissions would be reduced by $1.3 \mathrm{Mt} \mathrm{CO}_{2}$-eq. If the same area was replaced by temporary grass, $\mathrm{GHG}$ emissions would be reduced by $0.9 \mathrm{Mt}$ $\mathrm{CO}_{2}$-eq. Because slurry from dairy farms is normally used as organic manure for silage maize in the $\mathrm{EU}$, and $\mathrm{N}_{2} \mathrm{O}$ emissions from applied slurry are comparable with $\mathrm{N}_{2} \mathrm{O}$ emissions from grazing cattle (Food and Agriculture Organization 2010), no increases in $\mathrm{CH}_{4}$ and $\mathrm{N}_{2} \mathrm{O}$ emissions are expected. At the same time both water and energy resources would be saved because the production of grass requires less water and energy than the production of maize. In effect, conversion to permanent or temporary grassland could potentially have significant synergistic effects on water resources and energy security.

The use of leguminous crops such as clover, lentil, pea, and bean has the potential to reduce GHG emissions primarily because they do not need $\mathrm{N}$-fertilization and therefore save 50-200 kg N/ha depending on the crop they replace. Furthermore, leguminous crops have a pre-crop effect of $10-100 \mathrm{~kg} \mathrm{~N} / \mathrm{ha}$ on the subsequent crop. Estimates of GHG emissions from inorganic fertilizer production and application show that total GHG emissions range from 0.8 to $10.0 \mathrm{~kg} \mathrm{CO}_{2}-$ eq per kg fertilizer-N produced and from 0.8 to $6.7 \mathrm{~kg} \mathrm{CO}_{2}$ eq per $\mathrm{kg} \mathrm{N}$ applied in the field. See the section on nutrient management below. This means that for every $100 \mathrm{~kg}$ fertilizer-N saved, the emission of as much as $1.7 \mathrm{t} \mathrm{CO}_{2}$-eq is potentially avoided. Some leguminous crops have a higher demand for water than other crops, whereas other leguminous crops have lower demand, so the net effect on water resources is likely to be zero (Food and Agriculture Organization 1991). Because the production of inorganic fertilizers requires a large amount of energy, there are synergistic effects of using leguminous crops for energy security.

Increasing the fraction of crops with a high carbon content in crop residues, adopting high yielding varieties, replacing bare fallow with fallow crops, and introducing winter cover crops are crop management practices that will all increase the buildup of organic matter in the soil compared with business as usual, and thereby contribute to GHG mitigation. There are more synergies than trade-offs among these practices on one side, and water resources and energy security on the other side. All of the practices have synergistic effects on water resources, given that a higher level of soil organic matter will increase the water-holding capacity of the soil. High-yielding varieties will increase productivity and energy efficiency, thus offering the potential to reduce energy consumption. This is also the case for crops with high carbon content, as they could potentially increase the amount of biomass eligible for bioenergy production. However, trade-offs exist between bare fallow and cover crops on one side and energy security on the other side, as more energy is needed to cultivate the soil, and plant and plough down cover crops.

\section{Nutrient Management}

The IPCC mean estimate of the GHG-mitigation potential of improved nutrient management range from 0.33 to $0.62 \mathrm{t} \mathrm{CO}_{2}-$ $\mathrm{eq} / \mathrm{ha}^{-1} / \mathrm{yr}^{-1}$ in dry and moist climatic zones (Smith et al. 2007). Estimates show that the production of inorganic fertilizers consumes approximately $1.2 \%$ of the world's energy and is responsible for approximately $1.2 \%$ of global GHG emissions (Kongshaug 1998). Studies show that production of NPK (Nitrogen, Phosphorous, Potassium) fertilizers result in GHG emissions ranging from 0.8 to $10.0 \mathrm{~kg} \mathrm{CO}_{2}$-eq per $\mathrm{kg}$ of fertilizer-N depending on fertilizer production plant design and efficiency, emission control mechanisms, and rawmaterial inputs (Wood and Cowie 2004). Furthermore, the application of fertilizers in the field is estimated to emit from 0.25 to $2.25 \mathrm{~kg} \mathrm{~N}_{2} \mathrm{O}$ per $100 \mathrm{~kg} \mathrm{~N}$ (Smith et al 1997). The global-warming potential is 296 times higher for $\mathrm{N}_{2} \mathrm{O}$ compared with $\mathrm{CO}_{2}$, and the resulting total GHG emissions from fertilizer production and application therefore ranges from 1.5 to $16.7 \mathrm{~kg} \mathrm{CO}$-eq/kg fertilizer-N. Increasing fertilizer efficiency and reducing fertilizer inputs are the two primary ways to optimize nutrient management for reducing GHG emissions. Fertilizer efficiency can be increased by adjusting fertilizer amount, placement, and timing to minimize losses and meet actual crop demand. There are strong synergies between fertilizer efficiency on one side and water resources and energy security on the other, given that a reduction in fertilizer inputs will result in the water and energy used for fertilizer production being saved. Furthermore, a reduction in fertilizer inputs will also improve water quality, as the leaching of nutrients into groundwater and the pollution of surface water is reduced.

The consumption of nitrogenous fertilizer in the EU was $30,959,558$ tonnes in 2008 and the estimated nitrogen surplus is 7.1 million tonnes, corresponding to $55 \mathrm{~kg} \mathrm{~N} / \mathrm{ha}$. It follows that fertilizer efficiency in the EU can be increased substantially, which could potentially result in a reduction of 
GHG emissions in the range of $11-119 \mathrm{Mt} \mathrm{CO}_{2}-\mathrm{eq} / \mathrm{yr}^{-1}$ together with associated synergistic benefits for water and energy resources.

\section{Tillage and Residue Management}

The IPCC mean estimate of the GHG-mitigation potential of improved tillage and residue management range from 0.17 to $0.35 \mathrm{tCO}_{2}$-eq $/ \mathrm{ha}^{-1} \mathrm{yr}^{-1}$ in cool-dry and warm-dry climatic zones and from 0.53 to 0.72 in cool-moist and warm-moist climatic zones (Smith et al. 2007). By minimizing soil disturbance, conservation tillage practices such as no tillage and reduced tillage increase the buildup of soil organic matter and thereby mitigate GHG emissions, especially if combined with the retention of crop residues (Holland 2004). Conservation tillage practices and the incorporation of crop residues may have significant synergistic effects on water resources, as the resulting improved soil structure increases the water-holding capacity of the soil and leaves the soil less prone to leaching. Likewise, there is a synergistic effect of conservation tillage practices on energy security, as a substantial amount of energy is saved by not ploughing the soil. One could argue that there is a potential trade-off between incorporation of crop residues and energy security, because crop residues could potentially be used for bioenergy production.

\section{Water Management}

The IPCC mean estimate of the GHG-mitigation potential of improved water management is $1.14 \mathrm{t} \mathrm{CO}_{2}-\mathrm{eq} / \mathrm{ha}^{-1} / \mathrm{yr}^{-1}$ in all climatic zones (Smith et al. 2007). About $18 \%$ of global arable land is irrigated, and more efficient irrigation schemes may save $\mathrm{CO}_{2}$ used for irrigation and increase carbon sequestration through increased productivity. One of the most promising irrigation schemes that may be able to reduce GHG emissions is partial root-zone irrigation (PRI). This is a deficit irrigation strategy in which one half of the root zone is irrigated while the other half dries out (Shahnazari et al 2008). Irrigated and dry sides are periodically switched, and PRI has great potential to increase water-use efficiency and to maintain yield (Davies and Hartung 2004). Recent results for potato show that yield can be maintained using 30\% less water (Shahnazari et al. 2008). This method is superior in terms of enhancing $C$ concentration in the plant biomass, which could lead to more C losses from the soil (Wang et al. 2010). Therefore, it is possible that deficit irrigation schemes such as PRI could have synergistic effects by saving both water and energy resources. However, a comprehensive analysis of the energy used by the pumps to distribute the water through the pressurized pipes would need to be done to ensure a net energy gain is actually achieved. Water shortages and salinity threaten the sustainability of irrigated agriculture. The two are linked in several ways, as irrigated agriculture concentrates salts because water is taken up by the crop leaving salts behind in the root zone. Proper management must ensure that the salt is concentrated outside the root zone away from future water supplies for irrigation. Several types of management options are available. One of the key agronomic options is crop diversification using the different evapotranspiration patterns of different crops. Of course, this option is only feasible if there is a decent market for these crops, and farmers who grow them. Furthermore, recent innovations in the water treatment and irrigation industry have shown potential for the use of lowquality water resources such as reclaimed water or surface water in periurban agriculture for irrigation of vegetable crops without threatening food safety and quality. See, for example, Plauborg et al. (2010) and Marcussen et al. (2009). The successful use of lower quality water resources that require less energy-intensive treatment than higher quality water resources is another example of where energy gains can be achieved in water management. Other management options include improving the operation and maintenance of irrigation systems using information systems and to integrate water and soil management and their quality, for example, salinity aspects (Styczen et al. 2010).

\section{Soil Restoration}

Soil degradation has adverse impacts on all soil functions, including agronomic/biomass production, soil-filter function (environmental), engineering, cultural, and aesthetic functions. As summarized in Smith et al. (2007), a large proportion of agricultural lands have been degraded by excessive disturbance, erosion, organic matter loss, salinization, acidification, and other processes. Additionally, both agricultural and nonagricultural soils, such as urban and periurban soils, have lowered soil functionality given their pollution with organic chemicals and potentially toxic elements. For example, the European Environment Agency (EEA) member countries have reported 250,000 polluted sites (European Environment Agency 2007). Although only a few soil nondestructive methods exist for the treatment of persistent chemicals and nondegradable elements like heavy metals and metalloids, often soil functionality and carbon storage capacity can be partly restored by revegetation, applying organic substances such as manures, biosolids, and compost; reducing tillage, and retaining crop residues. The IPCC mean estimate of the GHG-mitigation potential of soil restoration of organic soils and degraded lands sees improved nutrient management range from 37.96 to $70.18 \mathrm{t} \mathrm{CO}_{2}-\mathrm{eq} / \mathrm{ha}^{-1} /$ $\mathrm{yr}^{-1}$ in cool and warm climatic zones (Smith et al. 2007). Reestablishing a high water table is the primary mitigation measure for organic soils. A combination of applying organic manures, reducing tillage, retaining crop residues, and conserving water is the primary mitigation measure for degraded land.

Generally, all mentioned soil restoration management measures will contribute to soil function synergies. Trade-offs may occur on the water-management side as groundwater quality may be adversely affected by the re-establishment of a high water table and the application of residue amendments. However, reintroducing high water tables may, in particular 
in the regions with increasing precipitation, increase risk of flooding of both agricultural and urban land, that again may negatively affect some of the soil functions and become tradeoffs between economic and environmental aspects of soil management.

\section{Bioenergy}

Bioenergy from agricultural crops and residues has the potential to displace GHG emissions from fossil fuels and, depending on the type of crop, increase soil carbon storage. The IPCC mean estimate of the soil carbon storage from bioenergy crops range from 0.17 to $0.35 \mathrm{t} \mathrm{CO}_{2}$-eq/ha $/ \mathrm{hr}^{-1}$ in cool-dry and warm-dry climatic zones and from 0.53 to 0.72 in cool-moist and warm-moist climatic zones (Smith et al. 2007). Correspondingly, the global potential to displace fossil fuel-based power plants and transport is estimated to be 1.22 $\mathrm{GtCO}_{2}$-eq yr ${ }^{-1}$ (Sims et al 2007) and $2.30 \mathrm{Gt} \mathrm{CO}_{2}$-eq/yr ${ }^{-1}(\mathrm{Kahn}$ Ribeiro et al. 2007). It is obvious that there are synergies between the production of bioenergy from arable crops and energy security, since bioenergy will reduce the dependence on fossil fuels (European Environment Agency 2008a). If measures to improve water use efficiency are integrated in the transition to bioenergy there may also be synergies with respect to water resources, but depending on the crop type bioenergy production could also cause trade-offs by intensifying water use and increase leaching of pesticides and nutrients (Freibauer et al. 2004, Jackson et al. 2005, Dalla Marta et al. 2011). Because bioenergy is in direct competition with food for the demand of a steady supply of arable crops, there is a major trade-off between bioenergy production and food security. Furthermore, the need for biomass in developed countries may require large imports, and an increased destruction of forests due to biofuel production is already evident in developing countries (European Environment Agency 2008b). Finally, even with ethanol transformation or heat combustion of crop residues to generate second generation biofuels and electricity, bioenergy production is still suboptimal from a strictly environmental viewpoint because the alternative option, that is, nonbiological renewables combined with other types of land use, such as permanent or temporary grassland, will result in a higher level of carbon sequestration and a lower pressure on water resources while at the same time also displacing fossil fuels.

The effects of the different GHG mitigating soil-management strategies on energy security and water resources are summarized in Table 1. It is evident that most of the soilmanagement strategies have synergistic effects on energy security and water resources whereas only a few trade-offs occur at the management level. But how do things look at the EU policy level? Are the relevant EU policies consistent and coherent in promoting GHG mitigating soil-management strategies?

\section{"DISHING THE DIRT" ON SOIL-MANAGEMENT STRATEGIES IN EU POLICIES}

Our intention here is not to explore individual member states' agricultural, energy, water, and climate change policies but, rather, the basis of the research is a "thin institutionalism" approach that emphasizes the need to assess policy design, settings, and institutional arrangements to better understand government priorities and choices (Young 2002, see also Pittock 2011). In the EU, in the areas of climate change, energy, water, and agriculture, the policy framing and settings are established at the supranational level, through European "directives" that set legally binding objectives and parameters that member states must pursue. Thus, it is important to examine the high-level, policy framing of the EU's sectoral regimes such as climate, energy, agriculture, and water, to ascertain what the priorities are and where the changes in behavior might occur. A 2010 Communication clearly indicates that the opportunity to use agriculture and specifically soil to contribute to climate mitigation has not been lost on the European Commission:

Although GHG emissions from agriculture in the EU have decreased by $20 \%$ since 1990 , further efforts are possible and will be required to meet the ambitious EU energy and climate agenda. It is important to further unlock the agricultural sector's potential to mitigate, adapt and make a positive contribution through GHG emission reduction, production efficiency measures including improvements in energy efficiency, biomass and renewable energy production, carbon sequestration and protection of carbon in soils based on innovation (European Commission 2010a).

However, the quotation also neatly captures some of the conflicts that arise in this domain: the extent to which improvements in energy efficiency, biomass and renewable energy production, carbon sequestration, and protection of carbon in soils are mutually reinforcing is contentious, particularly when the implications for Europe's water systems are added to the equation. The EU has extensive and comprehensive policies and legislation relating to agriculture, water, energy, and most recently, climate change. These policies are: the Common Agricultural Policy, the Water Framework Directive, and the Climate Action and Renewable Energy Package. We will briefly describe these policies and identify any explicit incentives contained within them to implement GHG-mitigating soil-management strategies, potential trade-offs among the policy regimes and, finally, lost opportunities to integrate across regimes. Our findings are summarized in Table 2, which shows that integration of soilmanagement strategies across the three policy regimes is limited. 
Table 1. Effects of GHG-mitigating soil-management strategies on energy security and water resources.

\begin{tabular}{|c|c|c|c|c|}
\hline Soil-management strategy & Management options & Effect on GHG emissions $\uparrow$ & $\begin{array}{l}\text { Effect on } \\
\text { energy security }\end{array}$ & $\begin{array}{l}\text { Effect on } \\
\text { water resources }\end{array}$ \\
\hline Crop management & $\begin{array}{l}\text { Permanent grassland } \\
\text { Temporary grassland } \\
\text { Leguminous crops } \\
\text { High carbon crops } \\
\text { High-yielding varieties } \\
\text { Replace bare fallow } \\
\text { Winter cover crops }\end{array}$ & $0.4-1.0 \mathrm{t} \mathrm{CO}_{2}-\mathrm{eq} / \mathrm{ha}^{-1} / \mathrm{yr}^{-1}$ & $\begin{array}{l}+ \\
+ \\
+ \\
+ \\
+ \\
- \\
-\end{array}$ & $\begin{array}{c}+ \\
+ \\
+/- \\
+ \\
+ \\
+ \\
+\end{array}$ \\
\hline Nutrient management & $\begin{array}{l}\text { Fertilizer efficiency } \\
\text { Reduce fertilizer inputs }\end{array}$ & $0.3-0.6 \mathrm{t} \mathrm{CO}_{2}-\mathrm{eq} / \mathrm{ha}^{-1} / \mathrm{yr}^{-1}$ & $\begin{array}{l}+ \\
+\end{array}$ & $\begin{array}{l}+ \\
+\end{array}$ \\
\hline Tillage and residue management & $\begin{array}{l}\text { Conservation tillage } \\
\text { Residue incorporation }\end{array}$ & $0.2-0.7 \mathrm{t} \mathrm{CO}_{2}-\mathrm{eq} / \mathrm{ha}^{-1} / \mathrm{yr}^{-1}$ & $\begin{array}{l}+ \\
(-)\end{array}$ & $\begin{array}{l}+ \\
+\end{array}$ \\
\hline Water management & $\begin{array}{l}\text { Deficit irrigation schemes } \\
\text { Crop diversification } \\
\text { Improve irrigation }\end{array}$ & $1.1 \mathrm{t} \mathrm{CO}_{2}-\mathrm{eq} / \mathrm{ha}^{-1} / \mathrm{yr}^{-1}$ & $\begin{array}{l}+ \\
+ \\
+\end{array}$ & $\begin{array}{l}+ \\
+ \\
+\end{array}$ \\
\hline Soil restoration & $\begin{array}{l}\text { Re-establish water table } \\
\text { Revegetation } \\
\text { Manure application }\end{array}$ & $38.0-70.2 \mathrm{t} \mathrm{CO}_{2}-\mathrm{eq} / \mathrm{ha}^{-1} / \mathrm{yr}^{-1}$ & $\begin{array}{l}- \\
- \\
-\end{array}$ & $\begin{array}{l}- \\
+ \\
-\end{array}$ \\
\hline Bioenergy & $\begin{array}{l}\text { First generation biofuels } \\
\text { Second generation biofuels } \\
\text { Electricity from biomass }\end{array}$ & $0.2-0.4 \mathrm{t} \mathrm{CO}_{2}-\mathrm{eq} / \mathrm{ha}^{-1} / \mathrm{yr}^{-1}$ & $\begin{array}{l}+ \\
+ \\
+\end{array}$ & $\begin{array}{l}+/- \\
+/- \\
+/-\end{array}$ \\
\hline
\end{tabular}

$\dagger($ Smith et al. 2007)

\section{Common Agricultural Policy (CAP) Bioenergy}

The Common Agricultural Policy (CAP) directly affects soil management because it encompasses a number of legally binding directives and regulations pertaining to land management. It also determines how and where agricultural activities will be subsidized. In essence, the CAP uses a combination of financial inducement and penalties to achieve its objectives, which are grouped into two "pillars." Pillar 1 relates to income support from direct payments, and Pillar 2 relates to rural development, including environmental objectives (European Council 2005a). With 37.7 billion euros committed in 2009, the major agricultural support through CAP comes in the form of direct payments to farmers. Under the Single Payment Support (SPS) scheme (Pillar 1), direct payment to the individual farmer is determined by earlier payments during a reference period or the number of hectares farmed during the first year of implementation of the scheme. To receive direct payments, farmers must respect standards of environmental protection, animal welfare, and food safety. They must also keep the land in good condition, a requirement known as "cross compliance." Cross-compliance rules apply to farmers who receive direct payments under the CAP's support schemes or, in some cases, under individual rural development programs in individual member states (see, for example, Department for Environment, Food and Rural Affairs 2011). There are three aspects to cross compliance:

- specific European legal requirements, known as Statutory Management Requirements (SMRs);

- standards, based on a European legal framework, that require farmers to keep their land in Good Agricultural and Environmental Condition (GAEC); 
Table 2. Integration of GHG-mitigating soil-management strategies in key EU legislation.

\begin{tabular}{|c|c|c|c|}
\hline & Common Agricultural Policy (CAP) $\dagger$ & $\begin{array}{l}\text { Climate and Renewable Energy Package } \\
\text { (CARE) }+\end{array}$ & $\begin{array}{l}\text { Water Framework Directive } \\
\text { (WFD)§ }\end{array}$ \\
\hline Crop management & Yes. & Partially. & No. \\
\hline $\begin{array}{l}\text {-Optimizing crop rotations. } \\
\text {-Increasing energy efficiency } \\
\text { by adopting high-yielding } \\
\text { varieties. } \\
\text {-Replacing bare fallow with } \\
\text { fallow crops. } \\
\text {-Introducing winter cover }\end{array}$ & $\begin{array}{l}\text { The CAP does not have specific } \\
\text { provisions relating to crop rotations or } \\
\text { crops but farm support is subject to } \\
\text { cross compliance; land must be kept in } \\
\text { "good agricultural and environmental } \\
\text { condition" (GAEC). A key } \\
\text { requirement is the completion of a Soil }\end{array}$ & $\begin{array}{l}\text { Crop management in CARE is only related to } \\
\text { bioenergy. The Sustainability Criteria for } \\
\text { bioenergy production encourages appropriate } \\
\text { crops be grown that have high yields and } \\
\text { minimal impact on the environment. However, } \\
\text { it does not address conflicts between land-use } \\
\text { decisions or the overall availability of land vis- }\end{array}$ & $\begin{array}{l}\text { The WFD does not directly } \\
\text { address crop management, } \\
\text { although the promotion of low- } \\
\text { water requiring crops is } \\
\text { mentioned as a supplementary } \\
\text { measure that member states } \\
\text { could consider. }\end{array}$ \\
\hline
\end{tabular}

Nutrient management

-Reducing fertilizer inputs. -Increasing fertilizer efficiency.

Tillage and residue management

-"No tillage" and "reduced tillage" practices.

-Retention of crop residues.

Water management

-Increase irrigation

efficiency.

-Promote deficient irrigation schemes.

-Crop diversification.
Yes.

The EU Nitrates Directive is part of the cross-compliance criteria. Nutrient management is also covered (indirectly) in GAEC.
No.

The sustainability criteria does not mention nutrient management specifically, and some studies (Dallamarta 2011) suggest that increased fertiliser use in some bioenergy crops delivers a net energy increase for biofuels.
Partially.

No specific provisions, but would be a key factor in achieving GAEC.

No.

The WFD is currently not part of the cross-compliance criteria, although it is expected to be included shortly. Nevertheless, member states are slow to implement WFD.
No.

There is a potential clash between the CARE Package's focus on bioenergy, which uses crop residues, and the potential retention of crop residues in the soil to increase the organic content of the soil.

Partially.

The production of biomass for bioenergy is devastating in some water-scarce regions (Dallamarta 2011), as the use of otherwise setaside land, and the choice of water-intensive crops, proves overwhelming for water supplies. Sustainability criteria for bioenergy addresses these conflicts, but there are no explicit options put forward, i.e., mandatory requirements for efficient irrigation schemes.
Yes.

Prescriptive provisions contained in WFD for "good ecological status" and "good chemical status" directly address nonpoint source pollution and nutrient management. However, implementation of WFD is poor.

No.

WFD does not address tillage and residue management, even though both would result in greater water-use efficiency.

Yes.

A key element of the WFD is that water-resource management should be undertaken at the river basin level, and that all member states must provide River Basin Management Plans (RBMPs) to the EU. Implementation is poor. There is no specific provision in the WFD relating to irrigation efficiency, or crop diversification. 
Soil restoration of organic soils and degraded lands

Bioenergy

-Appropriate crop choice. -Appropriate choice of land.
Yes, but weak

Requirements for GAEC to be defined by the member states, covering: protection of soil from erosion, maintenance of soil organic matter, maintenance of soil structure, and maintenance and avoidance of deterioration of habitats. The level of stringency and implementation varies markedly between member states and the EU regulation has been described as "broad brush."

No.

The CAP does not address soilmanagement strategies in relation to bioenergy production.
No.

The main threat to soil restoration from the CARE package comes from the $10 \%$ target for "biofuels," which could have direct and indirect negative effects on soil condition and functionality. The sustainability criteria for biofuels, which is not binding, includes a general prohibition on the use of biomass from land converted from forest, other high carbonstock areas, and highly biodiverse areas. It is up to the member states to ascertain which land this refers to.

Partially.

At least $10 \%$ of transport fuel must be renewable. Sustainability criteria, which include: 1) prohibition on the use of biomass from land converted from forest, other high carbon-stock areas, and highly biodiverse areas, 2) a common GHG-calculation methodology to ensure that minimum greenhouse gas savings from biomass are at least $35 \%, 3$ ) the differentiation of national support schemes in favor of installations that achieve high energyconversion efficiencies, and 4) monitoring of the origin of biomass.
No.

The link between soil quality and functionality, and water, is positive: higher soil quality means greater water retention and more efficient use of water by plants. Given this link, the WFD could usefully add "good soil status" as one of its key objectives.

No.

The WFD does not explicitly mention bioenergy or crop choice because it is largely designed to set parameters around water quality, and it is up to the individual member states to decide which activities should be managed, through the River Basin Management Plans.

$\dagger$ (European Council 1991, 2005a,b, 2009b)

$\ddagger$ (European Community 2001, 2003, European Council 2009c, European Commission 2010b)

$\S($ European Community 2000)

- an obligation to maintain a level of permanent pasture not included in the crop rotation for five years or more (this is not a cross-compliance obligation for individual farmers, but may become one in future years).

If farmers do not comply with the criteria, their SPS payments will be reduced. Thus, the regulation scheme embodies both a "carrot" approach in terms of payments, and a "stick" approach in the form of reduced payments. Requirements for GAEC practice are defined by the member states, but the relevant Council Regulation [(EC) No. 1782/2003] sets up a common framework which covers four issues: 1) protection of soil from erosion, 2) maintenance of soil organic matter, 3) maintenance of soil structure, and 4) maintenance and avoidance of deterioration of habitats. Thus, the GAEC requirement within the CAP is a key policy to encourage appropriate land and soil-management practices. Nevertheless, the EU requirements contained in GAEC are very broad and nonspecific. It remains the responsibility of the member states to adopt more stringent, enforceable regulation. In the United Kingdom, for example, farmers meet their EU GAEC obligation by undertaking a Soil Protection Review, but there is an additional, related Soil Management Plan under the UK Environmental Land Stewardship Scheme that requires a far more detailed assessment of fields, and that is subsequently used as the basis for planning and implementing management options to reduce the risk of runoff and soil loss (Department for Environment, Food and Rural Affairs 2005).

Theoretically, the SPS (Pillar 1) should also result in a higher diversification of land use, but even with decoupling from specific products, studies show that only $30 \%$ of farmers have plans to alter their mix of farm activities (Tranter et al. 2007) so, in its current form, the largest support scheme fails to promote the changes in soil management suggested by the IPCC. The support to specific products through market interventions is not linked to how the products are produced and, therefore, no specific sustainability goals are achieved. How well does the rural development scheme promote GHG mitigating soil-management strategies?

For Pillar 2, 13.6 billion euros were committed in 2009 for rural-development schemes. The purpose of the rural development support scheme is to improve competitiveness for farming and forestry, to protect the environment and the countryside, to improve the quality of life, and to promote diversification of the rural economy. In 2008, a health check of the CAP was performed and the member states agreed on a range of measures which directly or indirectly affect soil, 
water, and energy management: 1) decoupling subsidies linked to a specific product, 2) shifting subsidies to reinforce programs in the fields of climate change, renewable energy, water management, and biodiversity, and 3) abolishing the requirement for arable farmers to leave $10 \%$ of their land fallow (European Council 2009a). Of the three support schemes, the rural development support scheme has the largest potential for strengthening the incentive to implement soilmanagement strategies for mitigating GHG emissions, protecting water resources, and saving energy.

As defined by Council Regulation (EC) no 1698/2005 of 20 September 2005 (European Council 2005b), the aim of the European Agricultural Fund for Rural Development (EAFRD) is to improve: 1) the competitiveness of agriculture and forestry, 2) the environment and the countryside, and 3) the quality of life and the management of economic activity in rural areas. Only the second aim is directly linked to environmental sustainability. Furthermore, EAFRD is rather vague in defining how the environment can be improved, such that it covers: "a range of key issues for environmental protection such as biodiversity, Natura 2000 site management, protection of water and soil, climate-change mitigation, reduction of ammonia emissions and sustainable use of pesticides" (European Council 2005b). In effect, only a small proportion of the 13.6 billion euros allocated for rural development in 2009 will actually promote GHG mitigating soil-management strategies, and the abolition of the requirement for $10 \%$ fallow land will directly increase GHG emissions. The European Commission recognizes that Rural Development Plans do not currently fully use the potential to address climate change (European Commission 2009c). There is a shift appearing in the CAP reform process that is seeing greater emphasis placed on reinforcing Pillar 2 and providing more funding to programs in the fields of climate change, renewable energy, water management, and biodiversity. Of the three options identified in the November 2010 White Paper on the future of the CAP post-2013 (European Commission $2010 a$ ), only the last option would represent a concerted effort to put environmental issues on equal footing with income support and rural development. The main characteristics of Option 3 are:

Enhancement of environmental performance of the CAP through a mandatory "greening" component of direct payments by supporting environmental measures applicable across the whole of the EU territory. Priority should be given to actions addressing both climate and environment policy goals. These could take the form of simple, generalized, noncontractual and annual environmental actions that go beyond cross-compliance and are linked to agriculture (e.g. permanent pasture, green cover, crop rotation and ecological set-aside). In addition, the possibility of including the requirements of current NATURA 2000 areas and enhancing certain elements of GAEC standards should be analyzed.

There is also an expectation that the Water Framework Directive will be added to the list of Statutory Management Requirements, though this could take some time as it relies on member states finding consensus on what the operational obligations for farmers would be.

\section{Water Framework Directive (WFD)}

The purpose of the Water Framework Directive (WFD) is to achieve good qualitative and quantitative status in all EU water bodies by 2015 (European Community 2000). The goal is to reach a general protection of the aquatic ecology, specific protection of unique and valuable habitats, protection of drinking water resources, and protection of bathing water. A key element of the WFD is that water resource management is taking place at the river basin level and that all water bodies must reach "good ecological status" and "good chemical status" by 2015. For each river basin a River Basin Management Plan (RBMP) is made every six years in order to: 1 ) record the current status of water bodies within the river basin district, 2) set out the measures planned to meet the objectives of the WFD, and 3) act as the main reporting mechanism to the EU and the public.

With most countries having finalized their first RBMPs and specified the associated programs of measures, it is now evident that the plans in their current form will not be able to fully protect the water resources in the EU by 2015. Most plans do not adequately provide objectives and suggest measures to ensure good chemical and ecological status of surface waters, and in many cases an extension of the 2015 deadline or a lowering of the objectives is warranted according to the WFD provisions for exemptions to reach the objectives. Some plans suggest lower objectives for specific water bodies because they are already heavily modified by human activities. Several plans argue that public interest to secure employment, water supply, rural development, power supply and development of renewable energy makes it necessary to accept less stringent objectives. In other plans specific sectors, such as industry and agriculture which both have a huge effect on water quality, are not required to implement any measures for reducing point source and diffuse water pollution to meet the objectives of the WFD. Furthermore, effective measures to save water resources are only included in a few of the RBMPs. With respect to climate change only adaptation is mentioned, whereas mitigation options related to the use of water resources are not considered.

A possible reason for the apparently weak RBMPs is that governments and other authorities have realized that reaching the ambitious goals of the WFD is going to take a very long time and be very expensive. It is highly unlikely that the Commission will accept a lowering of the general objectives 
in the WFD, and it is more likely that the Commission will accept an extension of the deadline as long as the progress toward a better status can be documented. At this point it is very difficult to determine the general effect of the WFD on the promotion of GHG mitigating soil-management strategies. However, for the RBMPs that do include measures to be implemented by the agricultural sector some of the technologies and land use changes applied to reduce point source and diffuse pollution will also reduce GHG emissions.

\section{Climate Action and Renewable Energy (CARE) Package}

In the Climate Action and Renewable Energy (CARE) Package, the EU has committed to a $20 \%$ reduction in GHG emissions by 2020 and a $20 \%$ share of renewable energies in EU energy consumption by 2020 (European Commission $2009 b$ ). If there is an international agreement committing other developed countries to comparable emission reductions, the EU will commit to a $30 \%$ reduction of GHG emissions by 2020. As a part of the package, the EU has adopted eight different directives, of which the following three are the most relevant for this study: 1) promotion of the use of energy from renewable sources, 2) revision of the EU emission trading system (ETS), and 3) shared effort to reduce greenhouse gas emissions.

The directive promoting the use of energy from renewable sources amends, and will subsequently replace, previous directives on renewable energy and biofuels from 2001 and 2003. It sets a mandatory target of $20 \%$ renewables in overall energy consumption by 2020 and a mandatory $10 \%$ minimum share of biofuels in transport petrol and diesel consumption by 2020 . Even though the directive emphasizes that the binding character of the $10 \%$ target for biofuels requires that production is sustainable and second-generation biofuels are commercially available, it fails to address the fact that the land required to meet the $10 \%$ target exceeds the available land area in the EU. This will inevitably increase pressures on soil, water, and biodiversity within the EU. Meeting the target will also require a large import of biofuels, which will result in severe negative consequences for sustainability and food security in developing countries. Based on these facts, the Scientific Advisory Board of the EEA recommended that the 10\% target be completely suspended (European Environment Agency 2008b). Furthermore, the directive can be criticized for not seriously considering the potential for transportation to be based on electricity from biomass or other renewable energy sources instead of biofuels. In a recent study, Campbell et al. (2009) showed that transportation based on electricity from heat combustion of biomass is more than $100 \%$ as effective and reduces GHG emissions by $100 \%$ more than transportation based on first-generation biofuels. The directive does highlight that biogas from animal and organic waste has significant environmental advantages in terms of heat and power production, and it does address the importance of nonbiological renewables. However, it still fails to provide adequate incentives for developing new technologies in these areas. Ultimately, all energy policies that imply that organic matter is not returned to the soil are suboptimal, and will result in lower soil quality, a decreased quantity and quality of water resources, and a higher level of GHG emissions compared with policies that ensure that organic matter is incorporated in the soil (Blanco-Canqui and Lal 2007, Lal 2007). Therefore, from a strictly environmental point of view, sustainable energy policies should primarily focus on developing and applying technologies that generate energy from nonbiological renewables such as solar, wind, and geothermal.

The directive revising the ETS establishes an emissions cap for power companies and industry installations from 2013. The emissions cap will reach a $21 \%$ cut in 2020 and, at the same time, an increasing level of auctioning will gradually replace the previous allocation of free allowances. The directive adopting a shared effort to reduce GHG emissions specifies individual targets for all EU member states according to GDP per capita. Power companies, industry installations, and EU member states will be able to reduce emissions by increasing energy efficiency, implementing renewable energy technologies, applying carbon capture and storage technology, as well as establishing Clean Development Mechanism $(\mathrm{CDM})$ projects, which reduces emissions in developing countries. If the renewable energy technologies implemented within the EU and the CDM projects are based on biomass rather than nonbiological renewables there is certainly going to be trade-offs with soil quality and water resources.

In the absence of harmonized rules at the EU level, member states are free to put in place their own national schemes for solid and gaseous biomass used in electricity, heating, and cooling. In the 2010 report entitled "Sustainability requirements for the use of solid and gaseous biomass sources in electricity, heating, and cooling," the European Commission provides recommendations for member states to follow similar patterns and, most importantly, to be guided by a number of sustainability criteria (European Commission $2010 c$ ). In this way, it will be possible to minimize the risk of the development of varied and possibly incompatible criteria at the national level, leading to barriers to trade and limiting the growth of the bioenergy sector. The recommended criteria relate to: 1) a general prohibition on the use of biomass from land converted from forest, other high carbon-stock areas, and highly biodiverse areas, 2) a common greenhouse gas calculation methodology that could be used to ensure that minimum greenhouse gas savings from biomass are at least 35\%, rising to $50 \%$ in 2017 and $60 \%$ in 2018 for new installations, compared to the EU's fossil energy mix, 3) the differentiation of national support schemes in favor of installations that achieve high energy-conversion efficiencies, and 4) monitoring of the origin of biomass (European Commission 2010c). It is also recommended not to apply sustainability criteria to wastes, as these must already fulfill 
environmental rules in accordance with waste legislation at national and at European levels. Sustainability requirements should apply to larger energy producers of $1 \mathrm{MW}$ thermal or $1 \mathrm{MW}$ electrical capacity or above (European Commission 2010b).

Under the Renewable Energy Directive, member states were required to submit National Renewable Energy Action Plans in June 2010. These will be a key tool for identifying the EU's ambitions for exploiting its biomass potential, whether in electricity, heating, or transport. Following the submission of these plans and analysis of emerging national schemes, the Commission will consider, in 2011, whether additional measures such as common sustainability criteria at EU levels would be appropriate. The EC's findings had not been released at the time of writing.

\section{MOVES TOWARD A SOILS FRAMEWORK DIRECTIVE?}

The European Commission published a Thematic Strategy for Soil Protection in September 2006, including an impact assessment and proposal for a Soils Framework Directive (SFD). The rationale for the Soil Framework Directive was sound, and indeed mirrors the normative dimension to this paper; that greater integration and coordination between policies would result in more "win-win" solutions and less unintended trade-offs. As the Commission stated at the time," soil is a resource of common interest to the Community, although mainly private owned, and failure to protect it will undermine sustainability and long term competitiveness in Europe. Moreover, soil degradation has strong impacts on other areas of common interest to the Community, such as water, human health, climate change, nature and biodiversity protection, and food safety." (European Council 2006). In addition to establishing a common framework to protect soil on the basis of the principles of preservation of soil functions, prevention of soil degradation, mitigation of its effects, restoration of degraded soils, interestingly, the SFD also included the requirement to "identify, describe and assess the impact of some sectoral policies on soil degradation processes with a view to protect soil functions" (European Council 2006). Five years later and the SFD has failed to make any progress through the complex decision-making procedures of the EU, particularly as the countries opposing the directive include France, Germany, the United Kingdom, the Netherlands and Austria. Nevertheless, the potential for the SFD to act as a cross-sectoral, integrating tool remains plausible, as soil is an issue that spans the climate, water, agricultural/land-use, and energy policy domains.

\section{SYNERGIES AND TRADE-OFFS AT THE EU POLICY LEVEL}

There are several potential synergies and trade-offs among the CAP, the WFD, and the CARE package, including several options for better policy integration (see Table 3). Taking the
CAP first, there are currently only limited synergies with the WFD and CARE, but if the CAP subsidies are gradually shifted from SPS to rural development, as outlined in the 2010 White Paper on CAP Reform, and the support for rural development is focused on environmental objectives, a higher level of synergy is not unrealistic. Alternatively, the SPS requirement to protect the environment and keep the land in good condition could be strengthened with clear definitions of how soil and water resources must be managed to qualify for financial support. As of now, there are more trade-offs than synergies between CAP on the one side and WFD and CARE on the other. This is because current CAP policies allocate the major part of the funds according to earlier payments during a reference period or the number of hectares, and thereby delay the progression toward the development of more sustainable farming practices, which could contribute to meeting the objectives of WFD and CARE. The WFD has very limited synergies with CAP and CARE. Synergies with CAP can only be said to occur if the RBMPs include measures to be implemented by the agricultural sector, whereas trade-offs occur when the RBMPs argue that public interest in rural development makes it necessary to accept less stringent objectives. Because climate-change mitigation is not integrated in the WFD, there are no synergies between the WFD and CARE. One could even argue that the focus on adaptation in the WFD will result in trade-offs between WFD and CARE, because resources will be allocated to adaptation instead of mitigation.

In its current form, CARE has more trade-offs than synergies with the CAP and the WFD. Trade-offs with CAP are caused by the unbalanced focus on bioenergy, which may potentially harm rural development. Synergies with the CAP will increase if funds for rural development are increasingly allocated to farmers applying soil-management strategies with GHGmitigation potential. An example of a potential trade-off between CARE and the WFD includes the establishment of hydropower plants that, on the one hand, will have a GHGmitigating effect but, on the other hand, will put water resources at risk (see Opperman et al. 2011, Pittock et al. 2011). Finally, one should consider that, whereas the CAP provides funding for farmers providing environmental services, the case of synergies and trade-offs between the WFD and the CARE package is more complex because they actually compete for the same economic resources. To avoid unintended trade-offs caused by this competition between policies, they should be integrated to the greatest extent possible.

\section{DISCUSSION AND SPECULATION}

From the perspective of soil management, water resources, and climate change, all policies that imply that organic matter such as crop residues, animal manure, and other types of organic waste are not returned to the soil, are suboptimal and will result in lower soil quality, a decreased quantity and quality of water resources, and a higher level of GHG 
Table 3. Synergies and trade-offs among the Common Agricultural Policy (CAP), Water Framework Directive (WFD), and Climate Action and Energy (CARE) package.

\begin{tabular}{llll}
\hline \hline & Common Agricultural Policy & Water Framework Directive & Climate Action and Energy package \\
\hline Common Agricultural Policy & - & $\begin{array}{l}\text { EAFRD funding can be used to } \\
\text { support programs in the field of } \\
\text { water management. }\end{array}$ & $\begin{array}{l}\text { EAFRD funding can be used to } \\
\text { support programs in the field of } \\
\text { climate change. }\end{array}$ \\
-Synergies & - & $\begin{array}{l}\text { SPS delays development of } \\
\text { sustainable farming and thereby } \\
\text { delays meeting of WFD objectives. }\end{array}$ & $\begin{array}{l}\text { SPS delays development of } \\
\text { sustainable farming and thereby } \\
\text { delays meeting of CARE objectives. }\end{array}$ \\
-Trade-offs & - & $\begin{array}{l}\text { Allocate more funds directly to PES } \\
\text { and farmers implementing measures } \\
\text { specified by the RMBPs. }\end{array}$ & $\begin{array}{l}\text { Allocate more funds directly to PES } \\
\text { and farmers implementing measures } \\
\text { specified by CARE. }\end{array}$
\end{tabular}

Water Framework Directive

-Synergies

-Trade-offs

-Recommended action for policy integration

Climate Action and Energy package

-Synergies

-Trade-offs

-Recommended action for policy integration
When RMBPs include measures to be implemented by the agricultural sector.

When RMBPs argue that public interest in rural development makes it necessary to accept less stringent objectives.

Measures for the agricultural sector in all RMBPs, including GHGmitigating soil-management strategies.
None, as climate-change mitigation measures are not included in the WFD.

Resources allocated to adaption in RMBPs will reduce resources available for mitigation.

GHG-mitigation potential of watersaving measures should be quantified and counted as emission credits.
None, as climate change mitigation measures are not included in the WFD.

Establishment of hydropower plants may put water resources at risk.
Unbalanced focus on bioenergy may harm rural development.

Abandon the $10 \%$ minimum share of Applications to establish biofuels. hydropower plants should be

carefully evaluated against the

RMBP for the affected water body. emissions compared with policies that ensure that organic matter is incorporated in the soil. The synergy that exists between soil-management strategies to increase soil carbon on the one hand, and water resources and climate-change mitigation on the other hand, is conversely contrasted by tradeoffs between soil-management strategies to increase soil carbon and energy security. From the perspective of energy security, the primary concern is to meet increasing energy 
demands while at the same time reducing the dependence on fossil fuels. Inevitably this implies that energy policies will need a portfolio of all renewable sources of energy, including biomass in the short run. However, in the long run and from an environmental perspective, to be truly sustainable, energy policies should focus on energy generated from nonbiological renewable sources of energy such as solar, wind, and geothermal.

It is critical that policy makers understand the often complex links between the climate, energy, water, and food sectors. The challenge for policy makers and industry alike is to develop effective policies, processes, and analytical tools that integrate the links into policy and investment decisions. Despite the position of the EU as a leader in integrated policy development, it has so far failed to sufficiently coordinate the policies involving climate, energy, water, and food production. Indeed, in addition to our work, Pittock (2011), finds that there is a similar lack of water-management objectives in EU climate change policies. One reason for the lack of integration at the EU level is that the policies within these areas have been formulated by different Directorates General, which are influenced by different lobby groups and have different agendas and priorities. The recent creation of two new Directorates General for Energy and Climate Action (2010) shows that the EU is determined to strengthen the policies within these areas, but there is also a risk that this will weaken policy integration. Even if the European Commission's hopes to introduce a Soils Framework Directive had received more support from the key member states, it is conceivable that even a directive governing such a cross-sectoral issue as soil would fail to be sufficiently integrative.

There is a substantial body of knowledge on the tools, strategies, and mechanisms that can be employed to encourage greater integration among sectors and policy regimes (Lenschow 1997, Lafferty and Hovden 2003, Dovers 2005, Ross and Dovers 2007) and, in many respects, the European Commission's legal competences to draft and implement framework directives does provide a degree of integration and "big picture" foci that would otherwise be absent in member state policies. Other integrating mechanisms include horizontal and vertical coordinating mechanisms in public administrations (Lafferty and Hovden 2003), extensive stakeholder engagement (Ross and Dovers 2007), and appropriate legislative mechanisms such as strategic environmental assessment (Connor and Dovers 2004). The results summarized in Tables 2 and 3 suggest that there is much room for improvement. It is possible to identify a number of ways in which greater integration among, and indeed implementation of, policies might be achieved specifically in this case study. For instance, to increase synergies and reduce trade-offs among policies involving climate, energy, water, and food production at the EU level, an interdirectorate task force could be created to secure full policy integration between the CAP, the WFD, and the CARE package. Such a task force could identify opportunities for how the CAP might allocate a much larger part of the subsidies to payment for environmental services (PES) under the SPS and rural development support schemes. Furthermore, the environmental services eligible for support under SPS could be better defined according to the criteria set forth by the Consultative Group on International Agricultural Research (http://www.cifor.org/ pes/_ref/about/index.htm). They should be targeted toward management strategies mitigating GHG emissions, protecting water resources, and saving energy, while at the same time maintaining biodiversity. Ideally, CAP would be closely linked with the WFD and the CARE package in such a way that a major part of the CAP funding is allocated to farmers that implement measures specified by the RBMPs and the CARE package. This may yet come about if the WFD is included in the cross-compliance criteria, as is currently proposed. Of course, the recent debates around post-2013 CAP reform illustrate the intense political resistance that exists from some member states to placing greater obligations on farmers, so that even if the Commission may desire greater integration and "teeth" in EU-level policies, the political realities of the EU's multilevel governance structure may dampen this.

With respect to the Water Framework Directive, it could be made mandatory that all RBMPs include the crop, water, nutrient, tillage, and residue-management strategies that have the largest potential to mitigate GHG emissions in that basin. Likewise, effective measures to save water resources from soil management should be included in all RBMPs, and the GHGmitigating potential of these measures should be quantified and counted as GHG emission-reduction credits in the CARE package. Finally, the EU should enforce stringent objectives and carefully evaluate all suggested measures in the RBMPs, to maximize the outcome of the WFD process.

Perhaps one of the easiest and most obvious solutions with respect to the CARE package would be to completely abolish the target of a $10 \%$ minimum share of biofuels in transport petrol and diesel consumption by 2020 . Instead, a target could be placed on nonbiological renewables. Applications to establish hydropower plants should be carefully evaluated by consulting the RBMP associated with the affected water bodies to determine potential negative effects. The protection of soil and water resources should be fully integrated into CARE in such a way that soil- and water-management strategies with GHG-mitigating potential are credited for their emission savings.

\section{CONCLUSION}

There are many soil-management strategies that can be used to reduce GHG emissions and encourage more efficient water and energy use. Both the IPCC and the EU have recognized that policies aimed at encouraging crop rotations and 
appropriate crop choices, nutrient management, the introduction of efficient water management systems, the appropriate development of bioenergy, and soil-restoration techniques are the "low-hanging fruit" in terms of both energy and water security. Recognizing that EU framework directives and associated payment schemes largely determine policy priorities in EU member states, in this study, we examined the relevant EU policy frameworks to assess whether the potential synergies from soil-management strategies are being encouraged, where opportunities for integrating across policy regimes are missing or, conversely, where perverse outcomes or trade-offs are likely. Our findings suggest that whereas soilmanagement strategies are encouraged by the CAP, there is even greater scope to encourage soil-management strategies through the WFD and the CARE Package.

It is clear from the debate surrounding the post-2013 CAP reform process, and from the attempts by the European Commission to implement a Soil Framework Directive, that the European Commission is at least aware of the need for greater integration. It is the political realities of the EU governance structure that prevent it from achieving greater integration at the EU level. Future research building on these findings would involve undertaking a comparative analysis across member states to ascertain: 1) the extent to which MS policies are more comprehensive in their application of these directives than is legally required, 2) whether MS policies specifically address the uptake of the soil-management strategies identified in this research, and 3) whether institutional arrangements at the member-state level encourage greater integration and adoption of soilmanagement strategies to achieve the triple aims of climate mitigation, water, and energy security.

\section{RESPONSES TO THIS ARTICLE}

Responses to this article are invited. If accepted for publication, your response will be hyperlinked to the article. To submit a response, follow this link. To read responses already accepted, follow this link.

\section{LITERATURE CITED}

Amundsen, R. 2001. The carbon budget in soils. Annual Review of Earth and Planetary Sciences 29:535-562. http://d X.doi.org/10.1146/annurev.earth.29.1.535

Blanco-Canqui, H., and R. Lal. 2007. Soil and crop response to harvesting corn residues for biofuel production. Geoderma 141:355-362. http://dx.doi.org/10.1016/j.geoderma.2007.06.012

Campbell, A. 2008. Food, energy, water: conflicting insecurities. Journal of Soil and Water Conservation 63:149A-151A.

Campbell, J. E., D. B. Lobell, and C. B. Field. 2009. Greater transportation energy and GHG offsets from bioelectricity than ethanol. Science Magazine 324(5930):1055-1057.
Conant, R. T., K. Paustian, and E. T. Elliott. 2001. Grassland management and conversion into grassland: effects on soil carbon. Ecological Applications 11:343-355. http://dx.doi.or g/10.1890/1051-0761(2001)011[0343:GMACIG]2.0.CO;2

Connor, R., and S. Dovers. 2004. Institutional change for sustainable development. Edward Elgar, Cheltenham, UK.

Dalla Marta, A., F. Natali, M. Mancini, R. Ferrise, M. Bindi, and S. Orlandini. 2011. Energy and water use related to the cultivation of energy crops: a case study in the Tuscany region. Ecology and Society 16(2): 2. [online] URL: http://www.ecol ogyandsociety.org/vol16/iss2/art2/

Davies, W. J., and W. Hartung. 2004. Has extrapolation from biochemistry to crop functioning worked to sustain plant production under water scarcity? Proceedings of the Fourth International Crop Science Congress, Brisbane, Australia.

Department for Environment, Food and Rural Affairs (DEFRA). 2005. Producing a soil management plan for environmental stewarship. DEFRA, London, UK. [online] URL: http://adlib.everysite.co.uk/resources/000/107/821/soilmanagement-plan.pdf

Department for Environment, Food and Rural Affairs (DEFRA). 2011. The guide to cross compliance in England. DEFRA, London, UK. [online] URL: http://adlib.everysite.co. $\underline{\text { uk/adlib/defra/content.aspx } \text { doc }=249953 \& \mathrm{id}=249991}$

Dovers, S. 2005. Environment and sustainability policy: creation, implementation, evaluation. Federation, Sydney, Australia.

European Commission (EC). 2009. Communication from the Commission to the European Parliament, the Council, the European Economic and Social Committee and the Committee of the Region-20 20 by 2020 Europe's climate change opportunity. European Union, Brussels, Belgium. [online] URL: http://www.energy.eu/directives/com2008_0030en01.pdf

European Commission (EC). 2010a. Commission Communication on the CAP toward 2020: meeting the food, natural resources and territorial challenges of the future. COM (2010) 672. European Union, Brussels, Belgium. http://ec.europa.eu/agric ulture/cap-post-2013/communication/index_en.htm

European Commission (EC). 2010b. Communication 2010/C 160/02 from the Commission on the practical implementation of the EU biofuels and bioliquids sustainability scheme and on counting rules for biofuels. European Union, Brussels, Belgium. [online] URL: http://eur-lex.europa.eu/LexUriServ/ LexUriServ.do?uri=OJ:C:2010:160:0008:0016:EN:PDF

European Commission (EC). 2010c. Report from the Commission to the Council and the European Parliament on sustainability requirements for the use of solid and gaseous biomass sources in electricity, heating and cooling. European 
Union, Brussels, Belgium. [online] URL: http://ec.europa.eu/ energy/renewables/transparency platform/doc/2010 report/ com 201000113 report.pdf

European Community. 2000. Directive 2000/60/EC of the European Parliament and of the Council of 23 October 2000 establishing a framework for Community action in the field of water policy. Brussels, Belgium. [online] URL: http://eur-lex. europa.eu/LexUriServ/LexUriServ.do?uri=CELEX:32000L0060: EN:NOT

European Community. 2001. Directive 2001/77/EC of the European Parliament and of the Council of 27 September 2001 on the promotion of electricity from renewable energy sources in the internal electricity market. Brussels, Belgium. [online] URL: http://eur-lex.europa.eu/LexUriServ/LexUriServ.do?uri= CELEX:32001L0077:EN:NOT

European Community. 2003. Directive 2003/30/EC of the European Parliament and of the Council of 8 May 2003 on the promotion of the use of biofuels or other renewable fuels for transport. Brussels, Belgium. [online] URL: http://eur-lex. europa.eu/LexUriServ/LexUriServ.do?uri=OJ:L:2003:123:0042:0042: EN:PDF

European Council. 1991. Council Directive 91/676/EEC of 12 December 1991 concerning the protection of waters against pollution caused by nitrates from agricultural sources. European Community, Brussels, Belgium. [online] URL: $\underline{\text { htt }}$ p://eur-lex.europa.eu/LexUriServ/LexUriServ.do?uri=

\section{CELEX:31991L0676:EN:NOT}

European Council. 2005a. Council Regulation (EC) No 1290/2005 of 21 June 2005 on the financing of the common agricultural policy. European Union, Brussels, Belgium. [online] URL: http://eur-lex.europa.eu/LexUriServ/LexUriServ. do?uri=OJ:L:2005:209:0001:0025:EN:PDF

European Council. 2005b. Council Regulation (EC) No 1698/2005 of 20 September 2005 on support for rural development by the European Agricultural Fund for Rural Development (EAFRD). European Union, Brussels, Belgium. [online] URL: http://eur-lex.europa.eu/LexUriServ/LexUriServ. do?uri=OJ:L:2005:277:0001:0040:EN:PDF

European Council. 2006. Proposal for a Directive of the European Parliament and of the European Council establishing a framework for the protection of soil and amending Directive 2004/35/EC. European Union, Brussels, Belgium. [online] URL: http://ec.europa.eu/environment/soil/ pdf/com 20060232 en.pdf

European Council. 2009a. Council Regulation (EC) No 72/2009 of 19 January 2009 on modifications to the Common Agricultural Policy by amending Regulations (EC) No 247/2006, (EC) No 320/2006, (EC) No 1405/2006, (EC) No 1234/2007, (EC) No 3/2008 and (EC) No 479/2008 and repealing Regulations (EEC) No 1883/78, (EEC) No 1254/89, (EEC) No 2247/89, (EEC) No 2055/93, (EC) No 1868/94, (EC)
No 2596/97, (EC) No 1182/2005 and (EC) No 315/2007. European Union, Brussels, Belgium. http://eur-lex.europa.eu/ LexUriServ/LexUriServ.do?uri=OJ:L:2009:030:0001:0015:EN: PDF

European Council. 2009b. Council Regulation (EC) No 73/2009 of 19 January 2009 establishing common rules for direct support schemes for farmers under the Common Agricultural Policy and establishing certain support schemes for farmers, amending regulations (EC) No 1290/2005, (EC) No 247/2006, (EC) No 378/2007 and repealing Regulation (EC) No 1782/2003. European Union, Brussels, Belgium. [online] URL: http://eur-lex.europa.eu/LexUriServ/LexUriServ. do?uri=CELEX:32009R0073:EN:NOT

European Council. 2009c. Directive 2009/28/EC of the European Parliament and of the Council of 23 April 2009 on the promotion of the use of energy from renewable sources and amending and subsequently repealing Directives 2001/77/EC and 2003/30/EC. European Union, Brussels, Belgium. [online] URL: http://eur-lex.europa.eu/LexUriServ/LexUriServ. do?uri=OJ:L:2009:140:0016:0062:en:PDF

European Environment Agency (EEA). 2007. Progress in management of contaminated sites (CSI 015). EEA, Copenhagen, Denmark. [online] URL: http://themes.eea.europa. eu/IMS/IMS/ISpecs/ISpecification20041007131746/

IAssessment1152619898983/view content

European Environment Agency. 2008a. Maximising the environmental benefits of European bioenergy potential. Technical Report 10/2008, EEA, Copenhagen, Denmark.

European Environment Agency. 2008b. Opinion of the EEA scientific committee on the environmental impacts of biofuel utilisation in the EU. EEA, Copenhagen, Denmark. [online] URL: http://www.eea.europa.eu/about-us/governance/scientificcommittee/sc-opinions/sc-opinion-on-biofuels-march-2008

Eurostat. 2011. Agriculture database. [online] URL: http://ep p.eurostat.ec.europa.eu/portal/page/portal/agriculture/data/database

Food and Agriculture Organization (FAO). 1991. Water harvesting-a manual for the design and construction of water harvesting schemes for plant production. FAO, Rome, Italy.

Food and Agriculture Organization (FAO). 2010. Livestock's long shadow. FAO, Rome, Italy.

Freibauer, A., M. Rounsevell, P. Smith, and A. Verhagen. 2004. Carbon sequestration in the agricultural soils of Europe. Geoderma 122:1-23. http://dx.doi.org/10.1016/j.geoderma.20 04.01 .021

Holland, J. M. 2004. The environmental consequences of adopting conservation tillage in Europe: reviewing the evidence. Agriculture, Ecosystems and Environment 103:125. http://dx.doi.org/10.1016/j.agee.2003.12.018 
Hussey, K., and A. Schram. 2011 . Accounting for, and managing, the links between climate, energy, water and food in Europe: an opportunity for better policy integration and coordination.

In P. Winland, and G. Pearman, editors. Securing sustainable energy futures in Europe and Australia. Peter Lang, Brussels, Belgium.

Jackson, R. B., E. G. Jobbágy, R. Avissar, S. Baidya Roy, D. Barrett, C.W. Cook, K. A. Farley, D. C. le Maitre, B. A. McCarl, and B. C. Murray. 2005. Trading water for carbon with biological carbon sequestration. Science 310 (5756):1944-1947. http://dx.doi.org/10.1126/science.1119282

Kahn Ribeiro, S., S. Kobayashi, M. Beuthe, J. Gasca, D. Greene, D. S. Lee, Y. Muromachi, P. J. Newton, S. Plotkin, D. Sperling, R. Wit, and P. J. Zhou. 2007. Transport and its infrastructure. Pages 324-380 inB. Metz, O. R. Davidson, P. R. Bosch, R. Dave, and L.A. Meyer, editors. Climate change 2007: mitigation. Contribution of Working Group III to the Fourth Assessment Report of the Intergovernmental Panel on Climate Change. Cambridge University Press, Cambridge, UK and New York, New York, USA.

Kongshaug, G. 1998. Energy consumption and greenhouse gas emissions in fertilizer production. IFA Technical Conference, Marrakech, Morocco, 28 September-1 October 1998.

Lafferty, W. M., and E. Hovden. 2003. Environmental policy integration: towards an analytical framework. Environmental Politics 12(3):1-22. http://dx.doi.org/10.1080/096440104123 $\underline{31308254}$

Lal, R. 2007. Crop residues as soil amendments and feedstock for bioethanol production. Waste Management 28(4):747758. http://dx.doi.org/10.1016/j.wasman.2007.09.023

Lenschow, A., 1997. Variation in EC environmental policy integration: agency push within complex institutional structures. Journal of European Public Policy 4(1)109-127.

Lehmann, J., 2007. A handful of carbon. Nature 447:143-144.

Marcussen, H., Dalsgaard, A., and P.E. Holm. 2009. Element contents of water spinach (Ipomonea aquatica Forssk.), fish and sediment from a wetland production system that receives wastewater from Phnom Penh, Cambodia. Journal of Environmental Science and Health, Part A 44:67-77. http://d x.doi.org/10.1080/10934520802515376

Opperman, J. J., J. Royte, J. Banks, L. R. Day, and C. Apse. 2011. The Penobscot River, Maine, USA: a basin-scale approach to balancing power generation and ecosystem restoration. Ecology and Society 16(3): 7. [online] URL: http ://dx.doi.org/10.5751/ES-04117-160307
Pittock, J. 2011. National climate change policies and sustainable water management: conflicts and synergies. Ecology and Society 16(2): 25. [online] URL: http://www.eco logyandsociety.org/vol16/iss2/art25/

Plauborg, F., M. N. Andersen, F. Liu, J. Ensink, and R. Ragab. 2010. Safe and high quality food production using low quality waters and improved irrigation systems and management: SAFIR. Agricultural Water Management 98(3):377-384.

Reich, S. 2000. The four faces of institutionalism: public policy and a pluralistic perspective. Governance 13(4)501522. http://dx.doi.org/10.1111/0952-1895.00143

Rockman, B. A. 1994. The new institutionalism and the old institutions. New perspectives on American politics. Congressional Quarterly, Washington, D.C., USA.

Ross, A., and S. Dovers. 2007. Policy integration for sustainable NRM: joint research and policy learning. Final report of Land and Water Australia research project ANU-50. Land and Water Australia, Canberra, Australia.

Shahnazari A., S. H. Ahmadi, P. E. Laerke, F. Liu, F. Plauborg, S. E. Jacobsen, C. Jensen, and M. N. Andersen. 2008. Nitrogen dynamics in the soil-plant system under deficit and partial root-zone drying irrigation strategies in potatoes. European Journal of Agronomy 28(2):65-73. http://dx.doi.org/10.1016/ j.eja.2007.05.003

Sims, R. E. H., R. N. Schock, A. Adegbululgbe, J. Fenhann, I. Konstantinaviciute, W. Moomaw, H. B. Nimir, B. Schlamadinger, J. Torres-Martínez, J. Turner, Y. Uchiyama, S. J. V. Vuori, N. Wamukonya, and X. Zhang. 2007. Energy supply. Pages 253-315 in B. Metz, O. R. Davidson, P. R. Bosch, R. Dave, and L.A. Meyer, editors. Climate change 2007: mitigation. Contribution of Working Group III to the Fourth Assessment Report of the Intergovernmental Panel on Climate Change. Cambridge University Press, Cambridge, UK and New York, New York, USA.http://dx.doi.org/10.101 6/0168-9002(91)90714-2

Smith, P., D. Martino, Z. Cai, D. Gwary, H. Janzen, P. Kumar, B. McCarl, S. Ogle, F. O'Mara, C. Rice, B. Scholes, and O. Sirotenko. 2007. Agriculture. Pages 499-532 inB. Metz, O. R. Davidson, P. R. Bosch, R. Dave, and L.A. Meyer, editors. Climate change 2007: mitigation. Contribution of Working Group III to the Fourth Assessment Report of the Intergovernmental Panel on Climate Change. Cambridge University Press, Cambridge, UK and New York, New York, USA.

Smith P., D. Martino, Z. Cai, D. Gwary, H. Janzen, P. Kumar, B. McCarl, S. Ogle, F. O'Mara, C. Rice, B. Scholes, O. Sirotenko, M. Howden, T. McAllister, G. Pan, V. Romanenkov, U. Schneider, S. Towprayoon, M. Wattenbach, and J. Smith. 2008. Greenhouse gas mitigation in agriculture. 
Philosophical Transactions of the Royal Society 363:789-813. http://dx.doi.org/10.1098/rstb.2007.2184

Sohi, S. P., E. Krull, E. Lopez-Capel and R. Bol. 2010. A review of biochar and its use and function in soil. Advances in Agronomy 105:47-82. http://dx.doi.org/10.1016/S0065-2113 (10)05002-9

Soussana, J.-F., P. Loiseau, N. Vuichard, E. Ceschia, J. Balesdent, T. Chevallier, and D. Arrouays. 2004. Carbon cycling and sequestration opportunities in temperate grasslands. Soil Use and Management

Styczen, M., R. N. Poulsen, A. K. Falk, and G. H. Jørgensen. 2010. Management model for decision support when applying low quality water in irrigation. Agricultural Water Management 98(3):472-481. http://dx.doi.org/10.1016/j.agw at.2010.10.017

Tranter, R. B., A. Swinbank, M. J. Wooldridge, L. Costa, T. Knapp, G. P. J. Little, and M. L. Sottomayor. 2007. Implications for food production, land use and rural development of the European Union's single farm payment: indications from a survey of farmers' intentions in Germany, Portugal and the UK. Food Policy 32(5-6):656-671. http://dx .doi.org/10.1016/j.foodpol.2007.04.001

Wang, Y., F. Liu, M. N. Andersen, and C. R. Jensen. 2010. Carbon retention in the soil-plant system under different irrigation regimes. Agricultural Water Management 98 (3):419-424. http://dx.doi.org/10.1016/j.agwat.2010.07.010

Wood, S., and A. Cowie. 2004. A review of greenhouse gas emissionfactors for fertiliser production. International Energy Agency (IEA) Bioenergy Task 38, IEA, Paris, France. [online] URL: http://www.ieabioenergy-task38.org/publications/ GHG Emission Fertilizer\%20Production July2004.pdf.

Young, O. R. 2002. The institutional dimensions of environmental change: fit, interplay and scale. MIT Press, Boston, Massachussetts, USA. 